Мина М. ЂУРИЋ*

Универзитет у Београду

Филолошки факултет
Оригинални научни рад

Примљен: 20. 12. 2020.

Прихваћен: 28. 4. 2021.

\title{
ПОЛА ВЕКА ИНТЕРДИСЦИПЛИНАРНИХ ПРОУЧАВАњА КЊИЖЕВНОСТИ И МУЗИКЕ
}

\begin{abstract}
Имајући у виду ширину сагледаваних тема у оквирима области студија књижевности и музике, истраживање се бави разматрањима интердисциплинарних приступа проучавањима ових уметности, посебно развијаних током протеклих педесет и више година у земљи и свету. У раду се пореде начини на које су се из разноврсних теоријских перспектива ове интермедијалне везе представљале у контексту српске и светске науке о књижевности и музикологије. Узимајући у обзир и могућности будућих компаративних проучавања књижевности и музике, у раду се испитују постулати методолошких приступа, одабири истраживане грађе, резултати изведених анализа, као и њихови утицаји на даље аспекте промена у оквирима ове научне области.

Кључне речи: студије књижевности и музике, интердисциплинарни и интермедијални приступи.
\end{abstract}

Пред половину 20. века, у тежњи поспешивања компаративних и интердисциплинарних приступа књижевности у америчким високошколским установама у периоду након Другог светског рата, професор енглеске литературе са Универзитета у Џорџији и оснивач упоредних студија књижевности у овом академском центру понудио је једно од најранијих студиозних сагледавања могућности интермедијалних изучавања књижевности и музике (Brown 1948; уп. Gauss 1949: 132; Kinkeldey 1949: 52-54). Отварајући својом књигом интригантна питања о разноликим сферама прожимања двеју уметности и њихових изучавалачких дисциплина, Браун је већ 1948. године маркирао насловну синтагму (Brown 1948) која се чак и у другој деценији 21. века показала инспиративном и за концепцију часописа посвећеног представљању стваралаца из области музике и књижевности. ${ }^{1}$ Посебну врсту прекретнице у овој области међунаучних сусрета чинило је покретање Интернационалне

* mina.m.djuric@gmail.com

${ }^{1}$ До сада је објављено девет бројева електронског часописа Music \& Literature, чији су садржаји усмерени ка разноврсним поетикама музичких и књижевних уметника (в.: https://www. musicandliterature.org/issues; приступљено последњи пут 30. 10. 2020). 
асоцијације за студије речи и музике (The International Association for Word and Music Studies) у Грацу 1997. године, ${ }^{2}$ која је 1999. године понудила и публикацију усредсређену ка прецизирању поља истраживања ових компаративних студија (Bernhart, Scher, Wolf 1999), а већ следеће године и нови зборник радова приређен у част Келвина Брауна, оснивача многих интермедијалних анализа књижевности и музике (Cupers, Weisstein 2000). Уз то, истиче се барем још један изузетно значајан тренутак у динамизацији методолошких приступа наведеним међудисциплинарним релацијама, маркиран Шеровим анализама музичких потенцијала немачке књижевности (Scher 1968), о чијој утицајности сведоче и два издања његових следбеника у развијаној области, са текстовима у част Шеровог дела (Lodato, Aspden, Bernhart 2002), односно са сабраним Шеровим радовима (Scher, Bernhart, Wolf 2004). Дакле, када се у овако постављеним интернационалним оквирима осмотри ток развоја ове компаративне дисциплине, чини се да би значај вишедеценијског посвећивања аутора питањима интермедијалних проучавања књижевности и музике могао да се прати од 1948. године (Brown 1948) кроз, можда, нешто спорије премрежавање ране друге половине 20. века овим типовима истраживања, а посебно од 1968. године (Scher 1968) до садашњег тренутка, при чему процесу интензивнијег интересовања за ову област и ефектнијег окупљања експерата из различитих домена значајно доприноси оснивање поменуте асоцијације за интердисциплинарна истраживања књижевности и музике, одржавање бијеналних конференција и стварање богате библиотеке књига крајем 20. века и током првих деценија 21. века. ${ }^{3}$ Имајући у виду овакве опсеге историје једне научне области, у наредним сегментима рада представиће се и анализирати одређени теоријски изазови ове интердисциплинарне позиционираности, те понудити могућности и за њено будуће продубљено инкорпорирање у оквире студија српске књижевности и музике у контексту светске уметности и културе.

Иако је и пре Брауна проучавана улога музике у Мановим остварењима (уп. Reschke, Pollack 1992), деловање музике на књижевност, посебно на плану структуре Манових текстова, као и тип поетичких питања која су повезивала музичке и књижевне стараоце једног времена, у Брауновој студији оцењено је једним од најуспелијих сегмената истраживања (уп. Brown 1948; Gauss 1949: 132). Са друге стране, нарочито подстицајно у музиколошкој манологији чинио се и Шеров приступ „вербалној партитури” у Мановом роману Доктор Фаустус, где је одломак из романа тумачен као форма вербалне паралеле „Прелудијума” трећег чина Вагнерових Мајстора певача из Нирнберга (Scher 1968: 106-142). Скоро на средини између ова два упоришта дводеценијског тока анализиране научне области, налази се рад Виктора Жмегача о музици у Мановим делима, објављен на немачком језику 1959. године, који доноси и контекстуализацију Манових књижевних остварења у оквиру одређених друштвено-историјских околности (Žmegač 1959; уп.

\footnotetext{
${ }^{2}$ УП.: http://www.wordmusicstudies.net/index.html; приступљено последњи пут 30. 10. 2020.

3 Уп.: http://www.wordmusicstudies.net/wma_book_series.html; приступљено последњи пут 30. 10. 2020
} 
Schoolfield 1962: 136-138). У развоју ове интермедијалне научне дисциплине, уследиле су две деценије које су собом доносиле и синтетичке осврте ка начинима третирања музике у Мановим делима, формиране из перспектива различитих музичких и књижевних култура, међу којима су и истраживања српских проучавалаца (уп. Wachowicz 1961: 90-100; Димитријевић 1974: 6974). И мада су музиколошке интерпретације Манових текстова биле у фокусу разматрања истакнутог броја студија током 20. века и у првим деценијама 21. века - при чему су проучаваоце интересовали, између осталог, и концепт додекафоније у Мановим делима (Dahlhaus 1982: 33-49), релација музичког, семиотичког и семантичког у меланхолији магичног квадрата (Puschmann 1983), што упућује и ка читавој библиотеци текстова посвећеној Мановој рецепцији Дирера, затим однос мита и музике у Мановој прози (Scaff 1998), структура приповедне музике и музичке поетике у роману Доктор Фаустус (Danuser 2001: 293-320), монтажност композиционих аспеката и њихов однос према лајтмотиву и додекафонији у истом роману (Kropfinger 2001: 345-367), могућности за изучавања естетичких и филозофских поставки које су везивале Вагнера, Штрауса, Адорна и Мана, као и виђење улоге музике у разумевању позиције националног (Vaget 2006) и др. - чини се да је међу водећим темама књижевне и музиколошке експертизе Манових дела остало питање лајтмотива (уп. Wirtz 1975: 64-78) и полифоније литерарног опуса (уп. Górny 2017). Деценијама непресушна научна интересовања музиколога, естетичара, књижевних критичара, историчара и теоретичара књижевности за раскошну плејаду музичких тема везаних за Манову прозу очито проистиче и из релевантног значаја музичких промишљања овог књижевника (уп. Man 1980), али и громадних протежности свеукупне повезаности уметничких сусрета и тоталитета међудисциплинарних тековина у врхунским књижевноуметничким делима.

Међутим, овако конзистентна вишедеценијска истраживања музичких аспеката књижевних дела одређеног аутора постављају и питање шта све овај тип интердисциплинарних огледа отвара као могућности даљих приступа у повезивањима двеју уметности и научних студија које су посвећене пољима њихових прожимања. По угледу на заснованости музиколошке манологије, могао би да се додатно осветли простор испитивања и других књижевних стваралаца који су неговали и извесне музичке афнитете и из те перспективе уланчавали одређене музичке феномене као саставне елементе вербалне структуре својих текстова. Из те позиције могло би да се представи да би потенцијални сегменти библиографије научне области студија књижевности и музике засигурно обухватали и радове усмерене ка одређеним песницима, прозним ствараоцима или есејистима у чијим су текстовима на плану мотива, тема, композиције, доминирајућих метафора или неких других сфера заступљени музички елементи.

У назначеном смеру управо би се кроз вишедеценијску рецепцију пратили и развоји, нпр., музиколошке верленологије, која је, између осталог, подразумевала и преиспитивања односа формалног и семантичког у Верленовим поетичким схватањима музике поезије (Baudot 1968: 31-54) или пак 
начина композиторских приступа Верленовим стиховима (White 1992). У фокусима тог типа истраживања могле би да буду и музиколошке перспективе џојсологије, која је до сада проницљиво трагала и за изворима бројних музичких алузија у Џојсовим делима (Bowen 1975), повезујући то са важношћу музике у животу Џојса и његове породице или индикативности музичких облика за Џојсов литерарни рад (Smyth 2020), али се интересовала и за аспекте апсолутне музике од раних до позних Џојсових дела (Witen 2018). Музичке теме или пак музичке основе структуре књижевног дела биле су темељ интересовања и изучавалаца руске књижевности, а посебно подстицајне за музичка сагледавања поезије и прозе Бориса Пастернака, како у односу на проучавање улоге музике на мотивском и композиционом плану Пастернакових дела (Pomorska 1975), тако и из перспективе његових студија композиције и удела стечених знања у стварању књижевних текстова (Barnes 1976: 317-335). Присуство знатног броја музичких тема уочава се и у научним радовима посвећеним Хакслију, и то од уређених издања која и за будућа испитивања контекстуализују Хакслијеве музичке критике (Allis 2013) до проматрања идеја музичке композиције романа Контрапункт и удела који композитори попут Баха и/или Бетовена имају у овом књижевном делу (Рабинович, Бабкина 2017: 90-96). Ови примери управо показују колико су музиколошка испитивања дела светске књижевности током друге половине 20. века омогућила знатно усавршавање упоредних изучавања књижевности и музике и у 21. веку. У том контексту, отварају се евентуалности и за интермедијална испитивања других значајних аутора и остварења савремене светске књижевности, међу којима је, нпр., и проматрање романескног опуса Џона Апдајка, где се и на плану композиције, мотива, али и ликова запажају потенцијалне музичке паралеле, затим истицање лиричности нарације Петера Хандкеа, у чијем ритму реченице је вишеструко препозната вербално-музичка оркестрација, као и анализа начина интермедијалне ресемантизације музичког предлошка у Хандкеовом тексту, или пак интерпретација дела Орхана Памука, у коме је и лајтмотивска структура један од доминантних аспеката вишемедијалне наратолошке нити и др.

Тип интердисциплинарних истраживања који је био усмерен га сагледавању улоге музике у стваралаштву одређеног књижевног посленика био је постојан и у српској културној традицији и пре друге половине 20. века. Скоро у идентичном вишедеценијском распону токова студија књижевности и музике и њихових огледања на подијуму светске науке и уметности, и српска култура се у периодима до 1947, а посебно између 1947. и 2015. године посвећено бавила релацијама Вуковог рада и српске музичке сцене, и то нарочито маркирајући обзоре вуковских идеја које су се шириле и међу композиторима, а посвећено их је делио и Корнелије Станковић (уп. Ђурић Клајн 1947: 259-267) или пак подвлачећи начине на које је српска народна поезија вршила утицаје на европски круг композитора (Стефановић 2015: 581-583). У том смислу истиче се, на једној страни, и значај монографија упућених ка вишесмерним проматрањима музике и Његошевог опуса (Радовић 2001) или пак ка анализи облика у којима су стихови Десанке Макси- 
мовић стваралачки реципирани у музичким делима (Јовановић 2003), а, на другој страни, издвајају се и појединачна истраживања која су усредсређена на маркирање вредности музике у текстовима књижевних стваралаца - Лазе Костића (нпр. Марјановић 2020: 153-171), Богдана Поповића (Пено 2011: 45-58), Станислава Винавера (Tomašević 2018: 554-565) и др. О томе колико је комплексан удео музике у делима Момчила Настасијевића, као и у остварењима чланова његове породице, сведочи и чињеница о организацији целовитог интердисциплинарног научног скупа 2019. године, са потенцијалним аспектима и даљих интермедијалних истраживања Настасијевићевог опуса, на шта указује и објављен зборник радова (Поповић Млађеновић и др. 2021). Управо се стога и чини да би, и на основу одређених животних и поетичких опредељења аутора, могло да се промишља у правцу развијеније, континуиране поставке интердисциплинарних студија српске књижевности и музике, што би дозволило да се спроводе и посебне анализе музичких елемената у, нпр., Михаиловићевом делу, или Павићевих релација које се успостављају према музичкој уметности, као и композиција које су подстакнуте Павићевим остварењима, односно да се гранају истраживања која се тичу музичких одјека у текстовима Слободана Тишме, Давида Албахарија, Михајла Пантића, Бошка Сувајџића, Драгана Бошковића, Срђана Срдића и др. На овај начин музиколошка истраживања српске књижевности могла би да се сагледају и у односу на доминантна поетичка одређења и смене поетичких парадигми, односно да се аспекти анализе (пост)модернизацијских токова у оквирима двеју дисциплина упоредно прате и да се и на тај начин проматра целовитост уметничких одговора једне културе на изазове друштвено-историјског контекста.

Још један потенцијални правац интермедијалних истраживања књижевности и музике отворен је већ Брауновом студијом 1948. године и подразумевао је корпус заједничких појмова обеју уметности, међу којима су проучавалачку пажњу нарочито запосела и питања ритма, хармоније, контрапункта и др. (уп. Brown 1948; Gauss 1949: 132). У том домену, а у вези са аспектима метричке анализе стиха, евидентно је да су посебан допринос још двадесетих година 20. века начинила подробна структуралистичка и формалистичка испитивања поезије (уп. Жирмунский 1921; Жирмунский 1923; Томашевский 1923; Тынянов 1924; Эйхенбаум 1922; Якобсон 1923). ${ }^{4}$ Уз постојеће типове версификације, музичка истраживања стиха устоличила су и тактни mun, који акцентован део речи сагледава и у контексту наглашеног сегмента музичког такта (уп. Küper 1988: 274-281). Узимајући то у обзир, могуће је расветлити и ону врсту поезије која у свом ритму као доминирајући има такт

\footnotetext{
${ }^{4}$ У том контексту изузетна истраживања и међусобни дијалози вођени су и на пољу анализа српске версификације, а вршена су и поређења са истраживањима поезије других народа, о чему сведоче и вредни радови Светозара Матића, Радована Кошутића, Кирила Тарановског, Жарка Ружића, Светозара Петровића, Новице Петковића, Леона Којена и др. (уп. Којен 1996). Када се пак сродна грађа посматра из музиколошке перспективе, истичу се различити начини транспоновања акцената српске поезије у музичке облике соло песме, као и изазови са којима су се композитори сусретали у трагањима за одговарајућим решењима која су се тицала мелодијско-ритмичких обриса српских акцената (Петровић 2014).
} 
игре, а нарочито кола. С тим у вези, студијама књижевности и музике могло би да буде занимљиво и поновно испитивање Радичевићевих песама из перспективе тактне теорије стиха, а уз то посебно и музичке транспозиције текста у оквире партитура намењених вокалном и/или инструменталном извођењу (уп. Зечевић 1999) и сл.

Ипак, уз претежна испитивања односа музике и поезије, извесна проматрања веза књижевности и музике знатно су се усмеравала и ка прози (уп. Brown 1948; Gauss 1949: 132). Управо је у том контексту значајне могућности за испитивања актуелизовало и тумачење полифоније, које је Бахтин, кроз активирање поливалентног појма, установио у проучавањима романа Фјодора М. Достојевског (Бахтин 1929). Одређење полифоног књижевног дела и питања шта је у литерарном тексту контрапунктуално обележје покренула су врло сложена разматрања поводом (не)остваривости појма симултаности у књижевности (уп. Gauss 1949: 132), што је и раније већ допринело паралелном укључивању других интермедијалних интерпретација - нпр., текста, музике, визуелних и кинематографских елемената - и испитивања аспеката њихове једновремености (уп. Александров, Пудовкин, Эйзенштейн 1928: 5). Интригантно конципирана поља ових медијалних преплета установила су читав низ студија посвећених романескним делима, а усмереним ка сагледавањима књижевног текста који следи вишегласне одлике фугалних имитација на примеру једанаесте епизоде Уликса (Rogers 1990: 15-20), или ка изучавањима становишта временског контрапункта у роману Доктор Живаго (Гаспаров 1990: 223-242), при чему је посебна тежња управљана и ка томе да се наведени појмови не представљају само као метафоре, већ као структурални елементи текста (Górny 2017). Тако би и у неким наредним приликама улога, позиција и значења контрапункта у књижевном делу могли да буду анализирани из визуре тоталитета наративних гласова, у актуелизацији која се остварује на плану форме и значења вишегласних речи или мултилингвалних аспеката текста, у перспективи полифоне релације контрапунктуалне рецепције која се успоставља у графичком и смисаоном надовезивању нелинеарног текста маргина, фуснота, референци у односу на предлагану линеарност дела, у доменима различитих интертекстуалних веза и њихових ресемантизација и др.

Оваквој врсти динамизације у оквиру методолошких поставки нарочито доприноси и транспоновање појмова из једне у другу област, као и потреба да се успостави додатан корпус одредница који ће повезивати обе дисциплине. С тим у вези могло би да се промишља и о засебном лексикону појмова интердисциплинарног изучавања књижевности и музике. У том корпусу нашла би се и одређења која су до сада добила теоријска образложења или су пак интерпретативно установљена у односу на доминантну литерарну грађу - вербална музика (Scher 1968), литерарни контрапункт (Termer 1972: 3940), литерарна фуга (Нејтеј 2002: 96-123), музикализаичја фикичије (Wolf 1999), музичко писање књижевности (Dayan 2006), поетска музикологија (Barańczak 1972: 108-116), приповедна музика (Danuser 2001: 293-320) и др. Међу претпоставкама анализе заједничких одредница и разлика у оквирима 
вишемедијалних интерполација одређеног појма у књижевности и музици свакако би могло да буде подстицајно и истраживање поетских врста које се стварају или изводе уз музику, каденце у поезији и лирској прози модернизма, синкопе у распонима од везаног до слободног стиха, питања шта означава коду у поетском, а шта у прозном делу, дебате у вези са тим шта би указивало на импровизацију у књижевном остварењу, расправе поводом тога да ли постоји и алеаторика вербалног текста итд.

Такође, истраживање интертекстуалности у музичком делу представља једно од изразито продуктивних поља испитивања обеју дисциплина (Braun 2017: 57-69), које се унеколико наслања и на одређене постулате програмске музике. Као важно упориште бројних сусрета двеју уметности у том домену нуди се и оквир који повезује музичку драму и књижевну оперу (Dahlhaus 1983) и упућује на стециште разноврсних потенцијала интерпретација либрета транспонованог у музичке партитуре или пак евентуалних веза романа и опере (уп. Halliwell, Bernhart 2005). Посебно су драгоцена и истраживања која контекстуализују оперско питање у односу на културне постулате репрезентације националног идентитета на прелазима епоха (Milanović 2019: 231-251), а допринос томе дају и запажања поетичких зазивања у поставкама књижевних критичара, композитора и сликара одређеног времена (уп. Milojković-Đurić 1988: 687-701). Ако су уз то анализирани и одељци намењени и другим уметничким дешавањима, који су објављивани у књижевним часописима, нпр. и у посебној рубрици Српског књижевног гласника (Васић 2004: 39-59), тиме се утицало на још снажније осликавање културног контекста епохе и истицање потребе да се тај аспекат што веродостојније ревитализује не би ли и интердисциплинарна научна методологија почивала управо на конкретним примерима међусобних дијалога стваралаца. ${ }^{5}$ Стога се и закључује да би у контексту будућих интердисциплинарних истраживања одређених тема, мотива, митологема, референци које су заједничке књижевним текстовима и музичким делима од пресудног утицаја могао да буде и архивски потхрањен материјал заједничке грађе који би онда био доступан и музиколошким и књижевнотеоријским испитивањима. Као потенцијални пример таквог типа архива могао би да послужи интердисциплинарно развијани Архив „Дон Жуан” у Бечу, који је специјализован и за сакупљање грађе театарских и оперских изведби, као и других дела светске уметности која у фокусу имају фигуру Дон Жуана, ${ }^{6}$ што подстиче и разноврсне примере анализе транспозиција књижевног и музичког предлошка. ${ }^{7}$

Интердисциплинарност студија књижевности и музике током назначеног периода отварала је простор за дискусију и из позиције других друштвено-хуманистичких наука, нарочито филозофије и социологије. Скоро и упо-

\footnotetext{
${ }^{5}$ О сродној врсти контекстуализације дијалога двеју уметности и стваралаца одређене епохе сведочи и испитивање мемоарске грађе 19. века и ишчитавање начина на које су и књижевници перципирали музичка догађања једног времена (Марјановић 2019).

${ }^{6}$ Уп.: http://www.donjuanarchiv.at/; приступљено последњи пут 30. 10. 2020.

7 За пример интерпретације стваралачке рецепције Моцартовог предлошка о Дон Жуану у Миличићевом делу в. Ђурић 2018: 217-234.
} 
редно са Брауновим компаративним истраживањима књижевности и музике (Brown 1948), Адорно је 1949. године развио своју утицајну филозофску поставку сагледавања музичких домента прве половине 20. века на темељима материјалистичке критике (Adorno 1949). Токови промена у филозофији и социологији књижевности и музике, сродна грађа на којој се темеље одређени увиди тумача, улоге Ничеа, Шенберга или Кадинског у дефинисањима уметничких постулата који постају делатни у компаративним распонима различитих интермедијалних сагледавања, основа су за праћење упоредних кретања у оквирима уметности и њихових међусобних дијалога са другим хуманистичким наукама (уп. Donà 2006). Широк дијапазон интердисциплинарно постављених тема и заснованих критика пружио је услове да се продубе приступи и паралелним разматрањима изузетно интригантних проблема одсуства и тишине у музици и књижевности (Wolf, Bernhart 2016) или пак тумачења аутореференцијалности у музичким и књижевним делима (Bernhart, Wolf 2010). То указује и на могућности категоризације метадискурса музике који је суштински упућен на текст, односно на методологију стварања метамузичког дискурса који се у одређеним мерама ослања и на методологије других дисциплина, између осталог, и науке о књижевности.

У контексту интеркултуралних студија, као и истраживања поља културне дипломатије, потенцијално подручје међудисциплинарних сусрета књижевности и музике подразумева и испитивање улога музичких метафора у књижевним текстовима, а поготово у извештајима који су настајали током дипломатских служби српских књижевника у иностранству. Интерпретацијама у вези са тим које је значење и сврха инкорпорираних музичких метафора у књижевним делима, колико литерарни контекст музичких рефлексија посредује трагове одређених одјека из рецепције двадесетовековне историје, као и да ли постоји нешто што би могло да представља музичку дипломатију у књижевном тексту, нуди се простор за поновна ишчитавања, између осталог, и радова Милана Ракића, Станислава Винавера, Растка Петровића и др. Испитивање музичких метафора у текстовима књижевника из периода њихових дипломатских мисија у другим земљама могло би да представи истраживање културне дипломатије као метапоетичког аспекта литерарног текста који је изражен и кроз музички дискурс једне културе.

Међу најутицајнијим прекретницама у научној области која спаја изучавања књижевности и музике спадају и деловања Вернера Волфа, како у оквиру организације која се континуирано бави питањима ових интердисциплинарних студија, тако и у доменима радова кроз које се показује као изузетно посвећен проучавалац генезе и типологије интермедијалности у студијама књижевности (Wolf 2011). Један од сродних подухвата назначених интерпретација повезивао је идеје трансмедијалне нарације у оквирима плуримедијалних поставки које уз текст и музику подразумевају и визуелне аспекте (Bernhart, Urrows 2019), док се посебним испитивањем нагласио и вид перформативности који везује обе уметности (Bernhart 2011), што се на различите начине постаља паралелним и у односу на раније актуелизовану теорију адаптације (Hutcheon 2006). Имајући у виду поетичке промене 
у књижевности и музици у другој половини 20. и на почетку 21. века, очекивано је да анализа симболике одређеног инструмента, музичког облика, именовања композитора или дела, односно инкорпорирање читавих нотних записа у књижевном тексту подразумева и грађу музичких праваца који су у фокусу у датим деценијама (уп. Pantić, Albahari 1990; Paunović 2018). То све указује и на потребе даљих усавршавања метода компаративне херменеутике интердисциплинарних и интермедијалних студија књижевности и музике и перспективу њихове отворености за експертизе поетичких промена које у обе уметности доносе деценије 21. века.

Чини се да би у контексту интердисциплинарних разматрања студија књижевности и музике у оквирима других наука и уметности у неким од будућих корака ваљало промишљати и о својеврсној упоредној историји области ових истраживања, али и извесној музичкој читанци која би пружила могућности паралелне рецепције текста и музичког облика који су у одређеним периодима ступали у дијалоге, подстицали књижевне ствараоце на креативне одговоре, мотивисали композиторе на замашне музичке реакције и сл. ${ }^{8}$ Узимајући у обзир изузетну музичку компетентност бројних литерарних стваралаца на једној страни, као и књижевна интересовања музичара на другој, делује да би управо обухватан приступ, прилагођен различитим узрасним категоријама и интересентима успео да укаже на слојевитости стваралачких опредељења како уметника, тако и научника, као и да ослика истанчаност и непрекидност резонанце у оквиру комплексних интердисциплинарних и интеркултуралних кодова изучавања књижевности и музике. И на основу осврта на историју интердисциплинарне области студија књижевности и музике могло би да се закључи да ће у наредном периоду, уз даља усавршавања назначених поља истраживања, нарочит поглед бити усмерен и ка компаративним интердисциплинарним студијама књижевности и музике у контексту других наука и уметности.

\section{ЛИТЕРАТУРА}

Александров, Пудовкин, Эйзенштейн 1928: Григорий В. Александров, Всеволод И. Пудовкин, Сергей М. Эйзенштейн, „Будущее звуковой фильмы. Заявка", Советский экран, № 32, 5.

Бахтин 1929: Михаил М. Бахтин, Проблемы творчества Достоевского, Ленинград: Прибой.

Васић 2004: Александар Васић, „Музикографија Српског књижевног гласника и идеологија југословенства", Музикологија, бр. 4, 39-59.

Гаспаров 1990: Борис М. Гаспаров, „Временной контрапункт как формообразующий принцип романа Пастернака Доктор Живаго”, Дружба народов, №3, 223-242.

\footnotetext{
${ }^{8}$ На потенцијалне примере уметничког подухвата овакве врсте указао је, донекле, и Коља Мићевић у свом четворотомном пројекту Лирске историје музике (Мићевић 2011).
} 
Димитријевић 1974: Рашко Димитријевић, „Томас Ман и музика”, Домети, год. 1, бр. 1, јесен 1974, 69-74.

Ђурић 2018: Мина Ђурић, „'Величајна' граница модернистичког Дон Жуана у делу Сибета Миличића", у: Светлана Шеатовић, Сања Роић, ур., Jосип Сибе Миличић: време, простор, судбине, Београд: Институт за књижевност и уметност, Универзитетска библиотека „Светозар Марковић”; Zagreb: Filozofski fakultet Sveučilišta u Zagrebu, Centar za komparativnohistorijske i interkulturne studije, 217-234.

Ђурић Клајн 1947: Стана Ђурић Клајн, „Вук Караџић и српска музика”, Кьижевност, II, 9-10, септембар-октобар, 259-267.

Жирмунский 1921: Виктор М. Жирмунский, Композищия лирических стихотворений, Петербург: Опояз.

Жирмунский 1923: Виктор М. Жирмунский, Рифма: Её история и теория, Петербург: Academia.

Зечевић 1999: Ана Зечевић, прир., Ал' што певах неће пропанути: музичка транспозиција поезије Бранка Радичевића, Сремски Карловци: Бранково коло.

Јовановић 2003: Владимир Јовановић, Поезија Десанке Максимовић као инспирација музичких стваралаца, Београд: Задужбина „Десанка Максимовић".

Којен 1996: Леон Којен, Студије о српском стиху, Сремски Карловци, Нови Сад: Издавачка књижарница Зорана Стојановића.

Марјановић 2019: Наташа Марјановић, Музика у животу Срба у 19. веку: из мемоарске ризнице, Нови Сад: Матица српска; Београд: Музиколошки институт САНУ.

Марјановић 2020: Наташа Марјановић, „Свет музике у стваралаштву Лазе Костића”, Кюижевна историја, год. 52, бр. 171, 153-171.

Мићевић 2011: Коља Мићевић, Лирска историја музике, 1-4, Београд: Службени гласник.

Пено 2011: Весна Пено, „Теоријско-естетичка начела Богдана Поповића у његовим написима о музици", Зборник Матице српске за книжевност и језик, књ. 59, св. 1, 45-58.

Петровић 2014: Милена Петровић, Улога акцента у српској соло песми, Београд: Службени гласник.

Поповић Млађеновић и др. 2021: Тијана Поповић Млађеновић и др., ур., Матерьа мелодија Момчила Настасијевића: интердисииплинарне рефлексије, Београд: Факултет музичке уметности.

Рабинович, Бабкина 2017: Валерий С. Рабинович, Мария И. Бабкина, „Диалог музыки и литературы в творчестве Олдоса Хаксли", Вестник Пермского университета. Российская и зарубежная филология, 9 (2), 90-96.

Радовић 2001: Бранка Радовић, Његош и музика, Београд: Завод за уџбенике и наставна средства; Подгорица: Удружење композитора Црне Горе.

Стефановић 2015: Димитрије Стефановић, „Осврт на Вуково наслеђе у европској музици”, у: Нада Милошевић-Ђорђевић, ур., Вук Стефановић 
Каращић (1787-1864-2014), Београд: Српска академија наука и уметности, 581-583.

Томашевский 1923: Борис В. Томашевский, Русское стихосложение, Метрика, Петербург: Academia.

Тынянов 1924: Юрий Н. Тынянов, Проблема стихотворного языка, Ленинград: Academia.

Эйхенбаум 1922: Борис М. Эйхенбаум, Мелодика русского лирического сти$x a$, Петербург: Опояз.

Якобсон 1923: Роман О. Якобсон, О чешском стихе, преимущественно в сопоставлении в русским, Москва: Опояз; Берлин: МЛК.

Adorno 1949: Theodor W. Adorno, Philosophie der neuen Musik, Tübingen: Mohr Siebeck Verlag.

Allis 2013: Michael Allis, Temporaries and Eternals: The Music Criticism of Aldous Huxley, 1922-23, Newcastle: Cambridge Scholars Publishing.

Barańczak 1972: Anna Barańczak, „Poetycka 'muzykologia””, Teksty, nr 3, 108-116.

Barnes 1976: Christopher J. Barnes, „Boris Pasternak: The Musician-Poet and Composer", Slavica Hierosolymitana, vol 1, 317-335.

Baudot 1968: Alain Baudot, „Poésie et musique chez Verlaine : forme et signification", Études françaises, 4 (1), 31-54.

Bernhart, Scher, Wolf 1999: Walter Bernhart, Steven Paul Scher, Werner Wolf, eds., Word and Music Studies: Defining the Field, Leiden, The Netherlands: Brill.

Bernhart, Wolf 2010: Walter Bernhart, Werner Wolf, eds., Self-Reference in Literature and Music, Leiden, The Netherlands: Brill.

Bernhart 2011: Walter Bernhart, ed., Word and Music Studies: Essays on Performativity and on Surveying the Field, Amsterdam, New York: Rodopi.

Bernhart, Urrows 2019: Walter Bernhart, David Francis Urrows, eds., Music, Narrative, and the Moving Image: Varieties of Plurimedial Interrelations, Leiden, The Netherlands: Brill.

Bowen 1975: Zack R. Bowen, Musical Allusions in the Works of James Joyce: Early Poetry through Ulysses, Albany, New York: State University of New York Press.

Braun 2017: Lucinde Braun, „Intertextualität in der Musik - Čajkovskijs französische Musikzitate", in: Andrea Meyer-Fraatz (Hg.), unter Mitarbeit von Olga Sazontchik und Thomas Schmidt, Dialogizität - Intertextualität - Ambiguität: Ehrensymposion für Reinhard Lauer zum 80. Geburtstag, Wiesbaden: Harrassowitz Verlag.

Brown 1948: Calvin S. Brown, Music and Literature: A Comparison of the Arts, Athens, Georgia: The University of Georgia Press.

Cupers, Weisstein 2000: Jean-Louis Cupers, Ulrich Weisstein, eds., Musico-Poetics in Perspective, Leiden, The Netherlands: Brill.

Dahlhaus 1982: Carl Dahlhaus, „Fiktive Zwölftonmusik. Thomas Mann und Theodor W. Adorno", Jahrbuch der Deutschen Akademie für Sprache und Dichtung, 33-49. 
Dahlhaus 1983: Carl Dahlhaus, Vom Musikdrama zur Literaturoper: Aufsätze zur neueren Operngeschichte, München, Salzburg: Musikverlag Emil Katzbicher.

Danuser 2001: Hermann Danuser, „Erzählte Musik. Fiktive musikalische Poetik in Thomas Manns Doktor Faustus", in: Werner Röcke (Hg.), Thomas Mann, Doktor Faustus, 1947-1997, Bern: Peter Lang Verlag, 293-320.

Dayan 2006: Peter Dayan, Music Writing Literature, from Sand via Debussy to Derrida, Aldershot: Ashgate.

Donà 2006: Massimo Donà, Filosofia della musica, Milano: Bompiani.

Gauss 1949: Charles E. Gauss, „Brown, Calvin S. Music and Literature. A Comparison of the Arts. Athens, Georgia, 1948, The University of Georgia Press, pp. xi + 287", The Journal of Aesthetics and Art Criticism, vol. 8, no. 2, 132.

Górny 2017: Tomasz Górny, Polifonia: Od muzyki do literatury, Kraków: Towarzystwo Autorów i Wydawców Prac Naukowych Universitas.

Halliwell, Bernhart 2005: Michael Halliwell, Opera and the Novel: The Case of Henry James, edited by Walter Bernhart, Amsterdam: Rodopi.

Hejmej 2002: Andrzej Hejmej, „Literackie fugi ('Preludio e Fughe' U. Saby i 'Todesfuge' P. Celana)", Muzyczność dzieła literackiego, Wrocław: Wydawnictwo Uniwersytetu Wrocławskiego, 96-123.

Hutcheon 2006: Linda Hutcheon, A Theory of Adaptation, New York, London: Routledge.

Kinkeldey 1949: Otto Kinkeldey, „Calvin S. Brown. Music and Literature; a Comparison of the Arts. Athens, Ga.: The University of Georgia Press, 1948, xi, 287, pp.", Journal of the American Musicological Society, 2 (1), 52-54.

Kropfinger 2001: Klaus Kropfinger, ,'Montage' und 'Composition' im Faustus. Literarische Zwölftontechnik oder Leitmotivik?", in: Werner Röcke (Hg.), Thomas Mann, Doktor Faustus, 1947-1997, Bern: Peter Lang Verlag, 345-367.

Küper 1988: Christoph Küper, Sprache und Metrum: Semiotik und Linguistik des Verses, Tübingen: Niemeyer.

Lodato, Aspden, Bernhart 2002: Suzanne M. Lodato, Suzanne Aspden, Walter Bernhart, eds., Word and Music Studies: Essays in Honor of Steven Paul Scher and on Cultural Identity and the Musical Stage, Leiden, The Netherlands: Brill.

Man 1980: Tomas Man, Eseji, 1, s nemačkog preveli Tomislav Bekić, Boško Petrović, Petar Vujičić, Novi Sad: Matica srpska.

Milanović 2019: Biljana Milanović, „Opera Production of the Belgrade National Theatre at the Beginning of the $20^{\text {th }}$ Century: Between Political Rivalry and Contested Cultural Strategies", in: Jernej Weiss, ed., Vloga nacionalnih opernih gledališč v 20. in 21. stoletju, The Role of National Opera Houses in the $20^{\text {th }}$ and $21^{\text {st }}$ Centuries, Ljubljana: Koper, 231-251.

Milojković-Đurić 1988: Jelena Milojković-Đurić, „The Roles of Jovan Skerlić, Stevan Mokranjac, and Paja Jovanović in Serbian Cultural History, 19001914", Slavic Review, vol. 47, no. 4, 687-701.

Pantić, Albahari 1990: Mihajlo Pantić, David Albahari, prir., Uhvati ritam: omnibus: rok i književnost, Novi Sad: Polja.

Paunović 2018: Zoran Paunović, Doba heroja, Beograd: Geopoetika. 
Pomorska 1975: Krystyna Pomorska, Themes and Variations in Pasternak's Poetics, Lisse: Peter de Ridder Press.

Puschmann 1983: Rosemarie Puschmann, Magisches Quadrat und Melancholie in Thomas Manns Doktor Faustus. Von der musikalischen Struktur zum semantischen Beziehungsnetz, Bielefeld: AMPAL-Verlag.

Reschke, Pollack 1992: Claus Reschke, Howard Pollack, eds., German Literature and Music. An Aesthetic Fusion: 1890-1989, Leiden, The Netherlands: Brill, Fink.

Rogers 1990: Margaret Rogers, „Decoding the Fugue in 'Sirens”, James Joyce Literary Supplement, 4.1, 15-20.

Scaff 1998: Susan von Rohr Scaff, History, Myth, and Music: Thomas Mann's Timely Fiction, Columbia, South Carolina: Camden House.

Scher 1968: Steven Paul Scher, Verbal Music in German Literature, New Haven: Yale University Press.

Scher, Bernhart, Wolf 2004: Steven Paul Scher, Word and Music Studies: Essays on Literature and Music from 1967-2004, edited by Walter Bernhart and Werner Wolf, Leiden, The Netherlands: Brill.

Schoolfield 1962: George C. Schoolfield, „Die Musik im Schaffen Thomas Manns. Von Viktor Žmegač. (Zagreber Germanistische Studien: Heft I.) Zagreb: Philosophische Fakultät der Universität Zagreb. Seminar für deutsche Philologie, 1959, Pp. 109", The Journal of English and Germanic Philology, vol. 61, no. $1,136-138$.

Smyth 2020: Gerry Smyth, Music and Sound in the Life and Literature of James Joyce: Joyces Noyces, London: Palgrave MacMillan.

Termer 1972: Janusz Termer, „Literacki kontrapunkt”, Nowe Książki, nr 8, 39-40.

Tomašević 2018: Katarina Tomašević, „Rediscovering Stanislav Vinaver's Musical Universe. Fragments”, in: Sonja Marinković et al., eds., Challenges in Contemporary Musicology: Essays in Honor of Prof. Dr. Mirjana Veselinović-Hofman, Izazovi savremene muzikologije: eseji u čast prof. dr Mirjane Veselinović-Hofman, Belgrade: Faculty of Music, 554-565.

Vaget 2006: Hans Rudolf, Seelenzauber: Thomas Mann und die Musik, Frankfurt am Main: Fischer.

Wachowicz 1961: Zygmunt Wachowicz, „Muzyka w twórczości Tomasza Manna", Twórczość, nr 8, 90-100.

White 1992: Ruth White, Verlaine et les musiciens: Avec une chronologie des mises en musique et un essai de répertoire biographique des compositeurs, Paris: Minard Éditions, Coll. „La Thésothèque”.

Wirtz 1975: Erika A. Wirtz, „Zitat und Leitmotiv bei Thomas Mann”, in: Helmut Koopmann (Hg.), Thomas Mann: Wege der Forschung, Darmstadt: Wissenschaftliche Buchgesellschaft, 64-78.

Witen 2018: Michelle Witen, James Joyce and Absolute Music, London and New York: Bloomsbury.

Wolf 1999: Werner Wolf, The Musicalization of Fiction: A Study in the Theory and History of Intermediality, Amsterdam: Rodopi.

Wolf 2011: Werner Wolf, ,(Inter)mediality and the Study of Literature”, CLCWeb: Comparative Literature and Culture, 13.3. 
Wolf, Bernhart 2016: Werner Wolf, Walter Bernhart, eds., Silence and Absence in Literature and Music, Leiden, The Netherlands: Brill.

Žmegač 1959: Viktor Žmegač, Die Musik im Schaffen Thomas Manns, Zagreb: Philosophische Fakultät der Universität Zagreb.

Mina M. Đurić

\section{A HALF OF THE CENTURY OF INTERDISCIPLINARY STUDIES OF LITERATURE AND MUSIC}

\section{Summary}

The research deals with interdisciplinary approaches to the study of literature and music. This scientific field has been developed worldwide over the past fifty years and more. The paper analyzes how those intermediate connections have been presented in the context of Serbian and world culture. Taking into account the possibilities of future comparative studies of literature and music, the paper examines the postulates of methodological approaches, selections of researched material, results of performed analyses, as well as their influences on further aspects of changes within this scientific field. 